\title{
APPROACHES FOR MONITORING THE LEVEL OF PROVIDING MUNICIPAL ADMINISTRATIVE SERVICES ELECTRONICALLY (UKRAINIAN CASE)
}

\author{
VOLODYMYR STRELTSOV, ${ }^{1}$ PIOTR NIEDZIELSKI ${ }^{2}$
}

${ }^{1}$ Pomeranian University in Slupsk, Faculty of Management and Security, POLAND

e-mail:kbuapa@gmail.com

${ }^{2}$ University of Szczecin, Faculty of Economics and Management Services, POLAND

e-mail: piotr.niedzielski@wzieu.pl

RECEIVED
ACCEPTED
JEL
CLASSIFICATION

KEYWORDS

ABSTRACT
10 December 2018

28 December 2018

H75, L86

municipalities, administrative services, e-government, e-administration, monitoring, assessment

In the article several ways for creating methodology of monitoring e-government progress and perspectives on local level is analysed. This article seeking to review and contextualize the wealth of e-administration research in post-communist countries. On the basis of evolving monitoring practices some recommendations are proposed on how to improve the municipal e-services assessment quality.

\section{Introduction}

Municipalities increasingly active role during the time of building informational society patterns has drawn further attention to e-governance initiatives on regional and sub-regional levels. The crucial question for both academic and policy-making communities is: are local e-government monitoring tools for post-communist countries adequate for measuring progress in building truly effective, responsive and accountable local self-government? 
Substantial progress in Ukraine towards higher levels of e-government development was achieved not only by launching a single state portal of administrative services or introducing e-procurement system ProZorro, but also due to establishing e-government on regional and local levels. Social transformation with strong demand on the development of horizontal links between the state and its citizens lead to such efforts in developing e-government tools.

Another critical issue implementation of the regional or municipal programmes and projects for e-services development. Such activity is possible if there is a relevant management system with relatively high level of maturity. E-government development should be accompanied by formation of a relevant administrative culture that can facilitate effective implementation of e-administration projects.

Before appropriate answers are found, lingering challenges must be addressed. First, what is meant by municipal e-government? In the article e-government is associated with implementation of administrative processes (narrow definition). The whole range of governance including e-democracy, e-voting, e-procurement, e-education or e-healthcare hasn't been addressed.

UN e-readiness evaluation models not fully described perspectives of e-government not only on central, but also on local levels. It is not surprising that the Online Service Index (OSI), which is included in generalized EGDI (the United Nations E-Government Development Index) focus mainly on front-office (United Nations..., 2014).

Furthermore, the set of e-government monitoring concepts has been enriched with maturity, sophistication and some other indicators (Mukabeta Maumbe, Owei, Alexander, 2008; Kachwamba, Hussein, 2009; Lee, 2010; El-Qawasmeh, 2011; Ifinedo, Singh, 2011; Fesenko, Fesenko, 2016), a marketing model - on marketing indicators (Steyaert, 2004), a comprehensive framework - for the assessment the value of project post - implementation (Esteves, Joseph, 2008), a conceptual model - for measuring user satisfaction (Verdegem, Verleye, 2009), conceptual framework - for evaluation of public value (Karunasena, Deng, 2012; Bai, 2013; Ha, 2016), an integrated indicator model - for evaluation of e-government policies (Stanimirovic, Vintar, 2013). Although efforts are being made to create different e-government evaluation models at present there is no methodology that allows for flexible and comparative measurement of the phenomenon of e-government in a comprehensive and integral way (LunaReyes, Gil-Garcia, Romero, 2012), reference model as a reusable conceptual model for e-government assessment (Ostasius, Laukaitis, 2015).

Such range of studies aim to assess certain parameters or based on universal approaches which was adapted to each particular case. But a few researchers are focused on municipalities, which are playing much more essential role on Europe, as the most services are provided by local self-government bodies.

Second, how should an e-administration level should be studied, and which technology enrich solutions matter for post-communist countries? Many research studies are used technologically driven approaches based on assessment the level of technologic advancement. Some scholars have focused on the development of official websites and electronic document circulation system of local self-government bodies or have extended their analysis to different organizations (for example, Centers of Rendering Administrative Services in municipalities). More recently, quantitative research has investigated access to information for the public, to assist the transparency of local politics and combating corruption, to mobilize citizens and attract them to social and political processes. Main result of such researches is based on creating a rating of cities according to the certain indicators, and determined typical problems and best practices of introducing the electronic governance instruments. 
Therefore, as a result of different approaches adopted most scholars explores front-office as well as backoffice aspects of e-government from only one perspective either civic sector, businesses or public officials. This studies mainly focuses on provision of information services However, the values of local administration and their changes seems to be essential as the certain services in post-communist countries are still dependent from human being factor and administrative culture is not fully constructed for perceived citizens like partners. Also e-administration could be assessed from transformation point of view. Is it helpful for introducing new philosophy of public administration based on enhancement civic engagement in post-soviet countries.

\section{Objective and methodology}

The objective of this article is to give an overview of assessment municipal e-government concept and to reveal the evolution of monitoring tools applied in Ukraine. It should be started with a review of the current experience, discussed digital market in Ukraine and finally outlined the latest trends in e-government assessment process along with the key challenges in Ukraine.

It was used a method of theoretical, logical and systemic analysis of literature (scientific papers, policy documents and statistical sources) to study various views on monitoring the level of providing municipal e-services and outline recent trends in Ukraine. Also methods of comparative analysis (to compare various approach for building indicators) are applied in the article.

\section{Results and discussion}

So far, there have been a very few studies on evaluating performance of e-government on regional and local levels. It is a new field of research in Ukraine. Main Ukrainian studies can be referred to the "first generation" of evaluating e-government: focus on the problems of implementing the concept of e-Ukraine or review of the problem of assessing e-government effectiveness (Chmelyova, Zolotar, 2014; Kondratenko, 2011; Novosad, Seliverstov, Yurynets, 2011).

First complex attempt to assess the level of introducing e-administration instruments in Ukrainian regions has been performed in 2015. In previous years, the efficiency of sites of oblast councils, local councils of oblast centers, and councils of the second largest cities in Ukraine, have been already conducted by the Civil Society Institute NGO, in particular:

- 2008 - sites of oblast councils (NUTS 2),

- 2009 - sites of local councils of oblast centers (NUTS 3),

- 2010 - sites of the second largest cities (LAU) in Ukraine.

It is also important to note a complexity of the OSI measurement method, as the expected assessment involves qualitative rather than quantitative values. It concerns four stages of developing and providing online services (United Nations..., 2014 ):

a) stage 1: emerging information services: government websites providing information on public policies, governance, laws, regulations, relevant documents, and the types of government services provided;

b) stage 2: enhanced information services: government websites delivering enhanced one-way or simple two-way e-communication between government and citizens, such as downloadable forms of government services and applications; 
c) stage 3: transactional services: government websites engaged in two-way communication between the government and citizens, which can include requesting and receiving inputs on government policies, programmes, and regulations; citizens can get specialized data and download various forms after electronic authentication of their identity;

d) stage 4: connected services: government websites use Web 2.0 and other interactive tools to communicate with citizens. E-services and e-solutions cut across the departments and ministries in a seamless way; information, data and knowledge are transferred from government agencies through integrated applications. The government creates an environment that empowers citizens to be more involved in government activities to have a voice in developing and making decisions.

In early 2013, the Coalition of NGOs monitored the efficiency of introduced electronic governance system in 100 municipalities of Ukraine; the monitoring included the analysis of development and efficiency of using official websites and electronic document circulation system in local self-government bodies of selected cities (Kuspliak, Serenok, 2014). On the basis of the research was made a rating of local self-government bodies according to the activeness of using e-administration instruments; analyzed and summarized the results, developed recommendations for local self-government bodies regarding transparency, openness, and work optimization by the use of information and communications technologies.

Basic ground for e-administration monitoring is constitute Ukrainian legislation containing regulations on the use of information and communications technologies (ICT). Thus, a number of laws oblige local self-government bodies to use the ICT:

1. Law of Ukraine as of 6 September 2012 № 5203-VI On Administrative Services.

2. Law of Ukraine as of 13 January 2012 № 2939-VI On Access to Public Information.

3. Law of Ukraine as of 10 April 2012 № 2269-XII On the Rent of State and Communal Property.

4. Law of Ukraine as of 17 February 2012 № 3038-VI On Regulation of Urban Development.

5. Law of Ukraine as of 7 April 2012 № 3206-VI On Preventing and Combating Corruption.

Besides that, a number of Laws of Ukraine assume the use of ICT in activities of local self-government bodies. These laws are:

1. Law of Ukraine as of 13 September 2003 No. 1160-IV On the State Regulatory Policy in Spheres of Economic Activity.

2. Law of Ukraine as of 1 June 2010 No. 2289-VI On Public Procurement.

On the basis of these laws and partly on OSI measurement, the certain criteria for the assessment of front and back-offices of local councils were formed. Simultaneously, for taking into account some points, important for territorial communities, they were included in the list of criteria. During this attempt was used a system of indicators divided into five categories (Kuspliak, Serenok, 2014):

a) information access (contains 53 indicators: 35 - Information about activities of LSGB; 10 - information about the infrastructure and vital functions of a city; 8 - documents, that are recommended for publication. The maximum number of points in this category is 89 );

b) public feedback (contains 13 indicators, the maximum number of points - 15);

c) administrative services and access to public information (contains 16 indicators, the maximum number of points - 31);

d) user-friendly interface category (contains 8 indicators, the maximum number of points -8 ); 
e) timely content updates category (number of points for this category is 22).

It should be added that in the last category was assessed the promptitude of content updates, divided into eight types of information, according to the legislation:

- news - not later than 1 day (news for the current of previous day are published),

- draft regulatory acts - not later than 5 working days after publishing a notification about the promulgation of this regulatory act,

- other draft decisions - in 20 days before their adoption,

- decisions of city council - within 5 days after their signing,

- decisions of city mayor - within 5 days after their signing,

- decisions of executive bodies' chairmen - within 5 days after their signing,

- reports of city mayor - within 5 days after their signing,

- income declaration of city mayor for the last year - not later than after 30 days after its submission.

Thus, the official website of every selected local self-government body was analyzed according to 98 indicators, and the maximum number of points was 165 . According to the results of assessment of official websites of LSGBs, was created a rating of local self-government bodies according to the total number of points, and in every category.

In case of the Centers of Rendering Administrative Services (CRAS) research main attention was paid not to assess the quality of services provided by CRASs, but to analyze the quality of their basis functioning elements, like the electronic queue, information terminals and stands, accompanying services and conditions created for people with disabilities etc. This category contains 11 indicators, the maximum number of points - 13 (Kuspliak, Serenok, 2014).

Therefore, as a result of methodology adopted this monitoring concentrates only one perspective either citizens.

Later approach taking into account the developments that have taken place in recent years in the field of local e-government assessment, six key measurement dimensions were identified, namely (Donetsk and Lugansk..., 2018):

- measuring organizational capacity and development of technical infrastructure (back-office),

- measuring the information content of the official websites of the target authorities and ensuring the principles of the availability of web content in their work (front-office),

- measuring the use of e-participation tools in the target authorities (front-office),

- measuring access to public information in the target authorities in the form of open data (front-office),

- measuring access to administrative services electronically in the target authorities (front-office),

- measuring the scale of the practice of implementing electronic document management systems in the target authorities (back-office).

Further changes in finding proper indicators were made:

1. Green (C) means that there is convincing evidence of a high level of implementation (use) of e-government tools or activities.

2. Yellow (F) means that evidence of a high level of implementation (use) of e-government tools or activities is not so obvious.

3. Red (B) means there is strong evidence of problems with the implementation (use) of e-government tools or activities. 
4. Gray (C) means that information for evaluating the implementation (use) of e-government tools or activities is not enough.

This approach could be very hard compared with previous model where every selected local self-government body was analyzed according to the system of indicators corelated with points.

Very specific domain constitutes the assessment of the electronic document circulation system which is quite complicated. On addition some gaps in Ukrainian legislation concerning the implementation and use of the electronic document circulation system in activities of government bodies are. In 2003, two relevant laws were adopted in Ukraine - On electronic document and electronic document circulation, and On electronic signature. They determine basic notions and paperwork requirements, general principles of electronic document circulation, give the definition of concepts, features, legal status, constituent elements of a digital signature, characterize concepts and requirements for digital signature key certificates, conditions and safety measures, and general principles of operation of key certification centers. However, according to the experts, these laws pay a little attention to the mechanism of implementation the electronic document circulation system in governmental bodies.

Besides that, the Ukrainian legislation regulates the use of electronic document circulation by the Resolution of the Cabinet of Ministers of Ukraine of 10/28/2004 No. 1452 On Approval of the Procedure for Electronic Digital Signature Use by National and Local Government Bodies and State-Owned Enterprises, Institutions, and Organizations; Resolution of the Cabinet of Ministers of Ukraine of 10/28/2004 No. 1453 On Approval of the Standard Procedure for Electronic Document circulation in Executive Bodies; Resolution of the Cabinet of Ministers of Ukraine of 5/26/2004 No. 680 On Approval of the Procedure for Certification of Existence of an Electronic Document (Electronic Data) at a Certain Point of Time; Resolution of the Cabinet of Ministers of Ukraine of 7/17/2009 No. 733 On the official electronic document exchange by executive authorities.

Some Ukrainian cities are actively introducing the electronic document circulation system for a long time already, and have reached the certain results. However, there are a lot of factors which negatively influence the introduction of fully functioning electronic document circulation systems by local self-government bodies. First of all - it's the absence of the unified strategy for step-by-step introduction of electronic document circulation with certain financing; absence of standardized certified programs and security rules, unwillingness of the senior officials refuse manual administration, and paperwork culture of local governments' employees; the problem of data storage reliability and smooth operation of the system; budget limitations.

The exploratory findings need to be considered carefully. Yet, they are still interesting because there is a little empirical research which have explored this complex matter. But the following research limitations should be take into account:

a) hard to estimate the reliability of information, published on official sites of local self-government bodies;

b) some assessed information was situated on the website connected to the official website of a city council;

c) difficulties related to receiving delayed answers on information requests by city councils and also this answers are usually not full or contradictory;

d) questionable validity of monitoring the quality of CRASs basis functioning elements, as long as such monitoring would require more opinions of users to form objective results. 


\section{Conclusions}

Ukraine in time of transforming into a networked society trying to build horizontal connections between the state, municipalities and its citizens. In the course of adopting values of EU administrative space, the building of the effective and accountable e-government would help facilitate its capacity to manage resources, implement sound policies and better satisfy the need of its citizens. Therefore, it would be timely to set some light on the public value and how to use it for monitoring the e-government service performance because of its comprehensiveness.

"Second generation" of evaluating e-government in Ukraine focuses not only on provision of information services, but trying to find effective ways of involving citizens in public affairs on regional and local levels. Public value-based e-Government services monitoring should be understood at the regional and local levels.

Issues analysed by different approaches lead to different outcomes and give only part of the answer what is the level of e-government in a given local community. The correct evaluation of e-government on regional and local levels should more concentrate on effectiveness of municipalities; quality of public service delivery; and building transparency and accountability. Relationships among those dimensions, or how they relate each other in the field of e-Government performance can be clarified in future research.

\section{References}

Bai, W. (2013). A Public Value Based Framework for Evaluating the Performance of E-Government in China. Journal of iBusiness, 5 , 26-29. DOI: 10.4236/ib.2013.53b006.

Chmelyova, O., Zolotar, N. (2014). Doslidzennya problem formuvannya realizatsii kontsepcii elektronnogo uryaduvannya $v$ Ukraini ta strategichni napryamu ih vurishennya. Visnyk NTY «KhPI», 34, 1077, 189-196.

Donetsk and Lugansk oblast e-government assessment (2018). Retrieved from: www.ua.undp.org/content/ukraine/uk/home/library/ democratic_governance/egov-donetsk.html.

El-Qawasmeh, E. (2011). Assessment of the Jordanian E-Government: An Empirical Study. Journal of Emerging Trends in Engineering and Applied Sciences (JETEAS), 2 (4), 594-600.

Esteves, J., Joseph, R. C. (2008). A comprehensive framework for the assessment of eGovernment projects. Government information quarterly, 25 (1), 118-132. DOI: 10.1016/j.giq.2007.04.009.

Fesenko, T., Fesenko, G. (2016). E-readiness evaluation modelling for monitoring the national e-government programme (by the example of Ukraine). Eastern-European Journal of Enterprise Technologies, 28-35.

Ha, T. (2016). Empirically Testing the Public Value Based Conceptual Framework for Evaluating E-Government Performance in Vietnam. Modern Economy, 7, 140-152. DOI: 10.4236/me.2016.72016.

Ifinedo, P., Singh, M. (2011). Determinants of eGovernment maturity in the transition economies of Central and Eastern Europe. Electronic Journal of e-Government, 9 (2), 166-182.

Kachwamba, M., Hussein, A. (2009). Determinants of e-Government Maturity: Do Organizational Specific Factors Matter? Journal of US-China Public Administration, 6 (7), 1-8.

Karunasena, K., Deng, H. (2012). Critical factors for evaluating the public value of e-government in Sri Lanka. Government Information Quarterly, 29 (1), 76-84. DOI:10. 1016/j.giq.2011.04.005.

Kondratenko, O. (2011). Informatsiine zabezpechennya vushuh organiv derzavnoi vladu ta elektronne uryaduvannya. Naukovuy visnuk Instutytu miznarodnuh vidnosin NAY. Ser.: ekonomika, pravo, politologia, tyrusm, 1 (3), 66-73.

Kuspliak, I., Serenok, A. (2014). 100 cities - a step forward. Monitoring of introducing the electronic governing as the basic way to render administrative services electronically. Retrieved from: www.academia.edu/8116194/100_cities_a_step_forward._monitoring_ of_introducing_the_electronic_governing_as_the_basic_way_to_render_administrative_services_electronically.

Lee, J. (2010). 10 year retrospect on stage models of e-Government: A qualitative meta-synthesis. Government Information Quarterly, 27 (3), 220-230. DOI: 10.1016/j.giq.2009.12.009. 
Luna-Reyes, L.F., Gil-Garcia, J.R., Romero, G. (2012). Towards a multidimensional model for evaluating electronic government: Proposing a more comprehensive and integrative perspective. Government Information Quarterly, 29 (3), 324-334. DOI: 10.1016/j.giq.2012.03.001.

Mukabeta Maumbe, B., Owei, V., Alexander, H. (2008). Questioning the pace and pathway of e-government development in Africa: A case study of South Africa's Cape Gateway project. Government Information Quarterly, 25 (4), 757-777. DOI: 10.1016/j. giq.2007.08.007.

Novosad, V., Seliverstov, R., Yurynets, R. (2011). Ocinuyvannya efektuvnosti elektronnogo uryaduvannya. Kyiv: NADU.

Ostasius, E., Laukaitis, A. (2015). Reference Model for E-Government Monitoring, Evaluation and Benchmarking. In Inzinerine Ekonomika-Engineering Economics, 26 (3), 255-263.

Stanimirovic, D., Vintar, M. (2013). Conceptualization of an Integrated Indicator Model for the Evaluation of eGovernment Policies. Electronic Journal of e-Government, 11 (2), 293-307.

Steyaert, J.C. (2004). Measuring the performance of electronic government services. Information \& Management, 41 (3), 369-375. DOI: 10.1016/S0378-7206(03)00025-9.

United Nations E-Government Survey 2014: E-Government for the future we want (2014). New York: UN.

Verdegem, P., Verleye, G. (2009). User-centered E-Government in practice: A comprehensive model for measuring user satisfaction. Government Information Quarterly, 26 (3), 487-497. DOI: 10.1016/j.giq.2009.03.005.

Cite this article aS: Streltsov, V., Niedzielski, P. (2018). Approaches for monitoring the level of providing municipal administrative services electronically (Ukrainian case). European Journal of Service Management, 4 (28/2), 447-454. DOI: 10.18276/ejsm.2018.28/2-53. 